\title{
Removal of Ciprofloxacin Hydrochloride from Aqueous Solution by Pomegranate Peel Grown in Alziedab Agricultural Scheme - River Nile State, Sudan
}

\author{
Mutasim Elhag Elhussien, ", Maathir Ahmed Abde Iraheem², Rashida Mohammed Hussein ${ }^{3}$, \\ Mawia Hassan Elsaim ${ }^{4}$ \\ ${ }^{1}$ Department of Chemistry, Faculty of Education, Nile Valley University, Atbara, Sudan \\ ${ }^{2}$ Chemical Laboratories, Ministry of Health \& Population, Atbara, Sudan \\ ${ }^{3}$ Department of Chemistry, Inaya Medical College, Riyadh, Kingdom of Saudi Arabia \\ ${ }^{4}$ Department of Chemistry, Faculty of Science and Technology, Abdulatif Alhamed University of Technology, Merowe, Sudan
}

Email address:

mutasim1966@yahoo.com (M. E. Elhussien)

${ }^{*}$ Corresponding author

\section{To cite this article:}

Mutasim Elhag Elhussien, Maathir Ahmed Abdelraheem, Rashida Mohammed Hussein, Mawia Hassan Elsaim. Removal of Ciprofloxacin Hydrochloride from Aqueous Solution by Pomegranate Peel Grown in Alziedab Agricultural Scheme - River Nile State, Sudan. Advances in Biochemistry. Vol. 5, No. 5, 2017, pp. 89-96. doi: 10.11648/j.ab.20170505.12

Received: July 29, 2017; Accepted: August 24, 2017; Published: September 13, 2017

\begin{abstract}
Removal of Ciprofloxacin (CIP) antibiotic from aqueous solution onto Activated carbon derived from pomegranate peel wastes collected from Alziedab Agricultural Scheme at River Nile state, Sudan as a novel precursorby chemical activation with Potassium Hydroxide $(\mathrm{KOH})$, at specific condition of carbonization temperature at $500^{\circ} \mathrm{C}$ and 1 hour as a holding time and detonated as $(\mathrm{AC}(\mathrm{PPZS}) \mathrm{KOH}$. The obtained material was submitted to measurements of active surface area, Fourier Transform Infrared Spectroscopy (FTIR) analysis and scanning electron microscope (SEM). Batch-adsorption studied had been carried out to examine the adsorption capacity of the AC(PPZS)KOH for the removal of Ciprofloxacin from aqueous solution. The effect of various process parameters like $\mathrm{pH}$, initial antibiotic concentration, adsorbent dose, and contact time, on the efficiency of Ciprofloxacin removal was investigated. Maximum adsorption of Ciprofloxacin on AC(PPZS)KOH, $(86.4 \pm 5.7 \%)$ was observed at $\mathrm{pH}$ 8. The optimum adsorbent dose was determined as $0.05 \mathrm{~g}$ at $25^{\circ} \mathrm{C}$. Initial Ciprofloxacin concentrations has important effect on $\mathrm{AC}(\mathrm{PPZS}) \mathrm{KOH}$ in the studied range $(50-300 \mathrm{mg} / \mathrm{L})$ where the removal percentage increases as the antibiotic concentration decrease. The adsorption equilibrium data was well explained by Freundlich isotherm. The results reveal the Langmuir model is not able to describe the experimental data properly, poor less of fitting on $\mathrm{AC}(\mathrm{PPZS}) \mathrm{KOH}$. The Freundlich isotherm experimental data obtained showed (Correlation Coefficient, $\mathrm{R}^{2}=0.991$ ) higher than Langmuir isotherm, $\left.\mathrm{R}^{2}=0.919\right)$. The porous characteristics and adsorption efficiencies of prepared AC(PPZS)KOH were also investigated.
\end{abstract}

Keywords: Adsorption Isotherms, Activated Carbon, Pomegranate Peel, Ciprofloxacin, SEM, FTIR

\section{Introduction}

The removal of conventional pollutants, such as persistent organic pollutants was in focus for the last decades and so their behavior is well understood [1]. On the other side very little is known about the behavior of trace pollutants yet, which are present in the environment in extremely low concentrations. Pharmaceuticals are an example for the variety of man-made trace pollutants that are introduced in surface or subsurface water bodies [2]. Pharmaceuticals have been identified in the environment, including antibiotics, analgesics, psychiatric drugs, and natural and synthetic hormones [3]. Unused human pharmaceuticals may also enter the environment through 
landfill leachate $[4,5]$.

Adsorbents such as charcoal [6], polymers [7] and bentonite [8-12] in adsorption of drug, are recognized in clinical practice and environmental treatment. The safety, high adsorptive capacity, and high specific surface, have been accepted for a long time.

Pharmaceuticals poisoning also has been defined as a condition produced by any substance which when swallowed, inhaled, injected or absorbed precutaneously is capable of causing death, injury, toxic or untoward reactions [13].

Ciprofloxacin hydrochloride (CIP) is a synthetic chemotherapeutic antibiotic (1-cyclopropyl-6-fluoro-1, 4dihydro-4- oxo-7-(1-piperazinyl)-3-quinoline carboxylic acid), Its empirical formula is $\mathrm{C}_{17} \mathrm{H}_{18} \mathrm{FN}_{3} \mathrm{O}_{3}$ and its molecular weight is $331.4 \mathrm{~g} / \mathrm{mol}$. The broad spectrum antibiotic Ciprofloxacin (CIP) is used in human and veterinary medicine that is readily transported into the environment via domestic wastewaters and through direct runoff. (CIP) is a member of the Fluroquinolones antibiotics which is frequently used to the treatment of infections caused by bacteria aerobic like Klebsiella, Shigella which result in inflammation of the respiratory tract, inflammation of the ear, sinus, urinary tract, gonorrhea, inflammation of the skin and tissue infections and bone. In the event of over dose will cause poisoning and kidney pains and muscle acheate [14].

In the literature, several studies related to the adsorption of CIP to natural materials or components of natural materials have been published (activated carbon [15], activated charcoal and talc [16], date palm leaflets [17], montmorillonite [18], soil [19, 20, 21], dioctahedral clay minerals [22]; kaolinite [23]; modified coal fly ash [24]; aerobically digested biosolid [25], sawdust[26], birnessite, a layered manganese oxide [27], $\left(\mathrm{Fe}_{3} \mathrm{O}_{4} / \mathrm{C}\right)$ a new magnetic mesoporous carbon composite [28], Chitosan-Zn (II), Chitosan-Fe (III), Chitosan-Fe(II) microparticles [29], aluminum and hydrous oxides [30], andnano-sized magnetite [31]).

Adsorption of Ciprofloxacin from aqueous solutions by Pomegranate Peel wastes grown in Alziedab Agricultural Scheme (PPZS) has been studied in this work. Batch adsorption experiment were investigated to study the sorption behavior of (PPZS) towards Ciprofloxacin as a function of initial concentration, reaction time, adsorbent dosage and $\mathrm{pH}$. Time dependent showed that the adsorption process reached equilibrium at $30 \mathrm{~min}$. Two adsorption isotherms equations were employed including Freundlich and Langmuir. The equilibrium data could be well described by Freundlich equation for the adsorption on pomegranate peel waste.

\section{Materials and Methods}

The carbonaceous precursor used for preparation of activated carbon (AC) was Pomegranate Peel, collected from Alziedab Agricultural Scheme (PPZS) at River Nile State,
Sudan. Prior to use, sample was washed gently several times with distilled water to remove impurities present on the surface and then dried for one week. All chemical reagents used in this work were $\mathrm{BDH}$, used without further purification.

\subsection{Preparation of Activated Carbon}

Pomegranate Peel dried, crushed and grinded in a ball mill. The grinded sample was sieved to obtain particles ofuniform size90 mesh sieves. The precursor obtained was washed to remove surface bounded impurities and dried at $105^{\circ} \mathrm{C}$ for 24 h. $100 \mathrm{~g}$ of the precursor was impregnated with potassium hydroxide, $\mathrm{KOH}$ for $24 \mathrm{~h}$ in ratio of $1: 1.5$ at $50^{\circ} \mathrm{C}$ to achieve well penetration of the chemical into the interior of the precursor.

After impregnation, the sample was dried for $24 \mathrm{~h}$ at $105^{\circ} \mathrm{C}$. Activation treatment was carried out in a Carbolite ${ }^{\mathrm{TM}}$ furnace at $550^{\circ} \mathrm{C}$, using $25 \mathrm{~g}$ of the impregnated and dried sample. After cooling the solid residue to room temperature, washed with double distilled water followed by $0.1 \mathrm{M}$ hydrochloric acid $(\mathrm{HCl})$ to remove the residual chemical agents until the $\mathrm{pH}$ value of the rinsed water was neutral. The adsorbents prepared were denoted as $\mathrm{AC}(\mathrm{PPZS}) \mathrm{KOH}$, throughout the work.

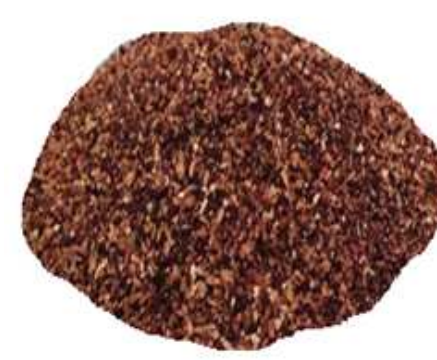

a)

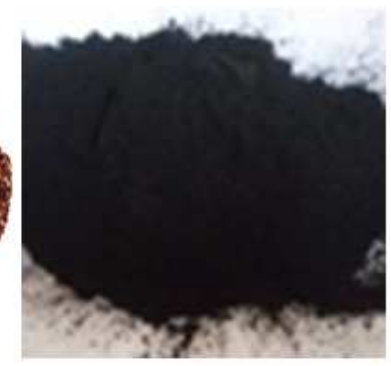

b)
Figure 1. Images of activated carbon obtained from Pomegranate Peel wastes grown in Alziedab Agricultural Scheme a) before and b) after carbonization process.

\subsection{Ciprofloxacin Standardization and Wavelength Selection}

Ciprofloxacin (CIP) used as adsorbate, obtained from Amipharama Laboratories Ltd, Sudan. A stock solution of $1000 \mathrm{mg} / \mathrm{Lwas}$ prepared by dissolving appropriate amount of (CIP) in $1000 \mathrm{ml}$ double distilled water in volumetric flask, different concentrations were prepared by diluting the stock solution to the initial concentrations ranging from 50-300 $\mathrm{mg} / \mathrm{L}$. Spectra of ciprofloxacin was measured by UV visible Jenway 7305 spectrophotometer, using $200 \mathrm{mg} / \mathrm{L}$ solution, scanned in the 200-300 nm UV regions. The maximum wavelength $\left(\lambda_{\max }\right)$ was observed at $274 \mathrm{~nm}$ which was adopted for absorbance measurement. Measurements of the absorbance of each standard solution (50, 100, 150, 200, 250 and $300 \mathrm{mg} / \mathrm{L}$ ) in $1 \mathrm{~cm}$ cuvette at $274 \mathrm{~nm}$, using double distilled water as a blank to verify Beer's - Lambert law were carried out [32]. 


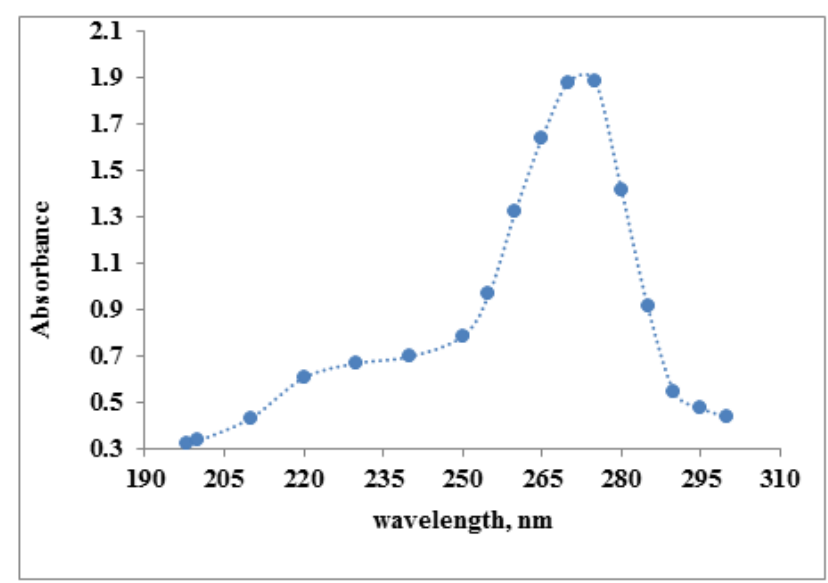

Figure 2. $U V$ - Visible Spectrophotometric Determination of $\lambda_{\max }$ for ciprofloxacin Absorption..

\subsection{Evaluation of Activated Carbon}

The activated carbon sample was evaluated two ways:

\subsubsection{Fourier Transform Infrared Spectroscopy}

The surface functional groups of the ACs were estimated by Fourier Transform Infrared (FTIR) spectroscopy (Shimadzu, Japan). FTIR spectra of the prepared AC(PPZS)KOH samples were recorded within $400-4000$ $\mathrm{cm}^{-1}$. The transmission spectra of the samples were recorded using the $\mathrm{KBr}$ pellet. About $1.0-2.0 \%$ of each sample was mixed with dry $\mathrm{KBr}$ and grinded in mortar. Then the samples were transferred to hydraulic press. The pellets which are homogeneous and transparent in appearance were dried overnight at $100^{\circ} \mathrm{C}$, and then inserted into the IR sample holder for the analysis.

\subsubsection{Scanning Electron Microscopy (SEM)}

SEM analysis of samples was performed by using (JSM6380LA) scanning electron microscope. The SEM instrument was operated at $5 \mathrm{kV} / \mathrm{SE}$ (Accelerating Voltage Machine), and $50^{\circ} \mathrm{C}$ inclination. Before analysis, all samples were ground and coated in a sputter coating unit (Edwards Vacuum Components Ltd., Sussex, England) to reduce charging and improve the secondary electron signals for imaging. The micrographs were recorded using photographic techniques.

\subsection{Effect of Process Parameters}

Batch adsorption experiments for adsorption of CIP on $\mathrm{AC}(\mathrm{PPZS}) \mathrm{KOH}$ were conducted using aqueous solutions of CIP. A stock solution of $1000 \mathrm{mg} / \mathrm{L}$ was prepared by dissolving appropriate weight of CIP from Amipharama Laboratories Ltd, Sudan. The stock solution was diluted as required to obtain different concentrations of antibiotic solutions. For each run, a definite amount of AC(PPZS)KOH was added to $25 \mathrm{ml}$ of CIP solution taken in $100 \mathrm{ml}$ Erlenmeyer flasks. All the adsorption experiments were carried out at constant temperature of $25^{\circ} \mathrm{C}$.

\subsubsection{Effect of $p H$}

Effect of $\mathrm{pH}$ on antibiotic adsorption was monitored over a
$\mathrm{pH}$ range of 2 to 12, using electronic $\mathrm{pH}-$ Meter (3510). In this study, $25 \mathrm{ml}$ of separate solutions $50 \mathrm{mg} / \mathrm{L}$ (CIP) was transferred into $100 \mathrm{ml}$ conical flasks shaking well for $30 \mathrm{~min}$ with $0.1 \mathrm{~g} \mathrm{AC}(\mathrm{PPZS}) \mathrm{KOH}$ at $25^{\circ} \mathrm{C}$. The mixture was filtered and the filtrate analyzed for residual CIP using UV visible Spectrophotometer (Jenway 7305).

\subsubsection{Effect of Contact Time}

In order to study the effect of contact time on the percent removal of (CIP) from aqueous solution, experiments were carried out at initial concentration of $50 \mathrm{mg} / \mathrm{L}$ using (0.1g)AC(PPZS)KOH dose and different contact times from 15 to 150 minutes The mixtures were filtered and residual of (CIP) in filtrate analyzed spectrophotometrically.

\subsubsection{Effect of Adsorbent Dosage}

To determine the optimum adsorbent dosage, experiments were carried out by adding different weights of $\mathrm{AC}(\mathrm{PPZS}) \mathrm{KOH}$ ranging from $(0.025$ to $0.2 \mathrm{~g})$ to $20 \mathrm{ml}$ of desired concentration of (CIP) in $50 \mathrm{ml}$ conical flask at $\mathrm{pH} 8$, temperature $25^{\circ} \mathrm{C}$ and shaken for $30 \mathrm{~min}$. Aliquots concentration was analyzed to determine the extent of adsorption of (CIP) at equilibrium.

\subsubsection{Effect of Initial Drug Concentration}

$20 \mathrm{ml}$ solutions of CIP drug with different initial concentrations (50-300 mg/L) were contacted with optimized adsorbent dosage $0.1 \mathrm{~g}$ and $\mathrm{pH}$ 8. The mixtures were shaken well for $30 \mathrm{~min}$ at $25^{\circ} \mathrm{C}$. The mixtures were filtered and filtrate analyzed for residual drug concentrations.

\subsection{Equilibrium Adsorption Studies}

Batch adsorption experiments were studied by adding 0.1 $\mathrm{g}$ of AC(PPZS)KOH in to $100 \mathrm{ml}$ conical flask filled with 20 $\mathrm{ml}$ of CIP solution of known initial concentration ranging from 50 to $300 \mathrm{mgl}^{-1}$ at $\mathrm{pH}$ 8. The conical flasks were sealed and shaken well at $25^{\circ} \mathrm{C}$ for $30 \mathrm{~min}$; the samples were then withdrawn and filtered. The residual CIP concentration at equilibrium was estimated spectrophotometrically and the amount adsorbed, $\mathrm{q}_{\mathrm{e}}(\mathrm{mg} / \mathrm{g})$ was calculated using the following expressions $[33,34]$ :

$$
\begin{gathered}
q_{e}=(V / w)\left(C_{\mathrm{o}}-C_{e}\right) \\
\% \text { Removal }=100\left(C_{\mathrm{o}}-C_{e}\right) / C_{\mathrm{o}}
\end{gathered}
$$

Where $\mathrm{q}_{\mathrm{e}}$ is the amount of the (CIP) adsorbed by the $\mathrm{AC}(\mathrm{PPZS}) \mathrm{KOH}$ sample in $(\mathrm{mg} / \mathrm{g}), \mathrm{C}_{\mathrm{o}}$ and $\mathrm{C}_{\mathrm{e}}$ are the initial and equilibrium concentrations of (CIP) respectively in $(\mathrm{mg} / \mathrm{L}), \mathrm{V}$ is the volume of the solution treated in $(\mathrm{L})$ and $\mathrm{w}$ is the adsorbent mass of $\mathrm{AC}(\mathrm{PPZS}) \mathrm{KOH})$ in $(\mathrm{g})$.

From the Beer's- Lambert's plot for the Ciprofloxacin Hydrochloride drug previously made, the amount of free drug in solution was determined. From the results, the time to attain equilibrium for adsorbent was determined.

The equilibrium data were recorded for investigations using Freundlich and Langmuir isotherms models [35, 36]. 


\section{Results and Discussion}

\subsection{Evaluation of the Prepared Activated Carbon Sample}

The obtained results from Fourier Transform Infrared Spectrum(IR) and Scanning Electron Microscopy (SEM) were used to evaluate the prepared activated carbon sample as follow:

\subsubsection{Fourier Transform Infrared Spectroscopy (FTIR)}

The FTIR analysis of prepared AC(PPZS)KOH reveals a simple spectrum, shown on figure 3 . The spectrum showed the absorption bands at these regions $\left(2900-3650 \mathrm{~cm}^{-1}\right)$, $\left(1520-1650 \mathrm{~cm}^{-1}\right),\left(1000-1260 \mathrm{~cm}^{-1}\right)$ and $\left(472-419 \mathrm{~cm}^{-1}\right)$ The broad peak at around $3438 \mathrm{~cm}^{-1}$ is assigned to presence of $\mathrm{OH}$ groups (adsorbed moisture) on surface. The sample showed a broad band with a maxima at $2900 \mathrm{~cm}^{-1}$ which is attributed to $\mathrm{C}-\mathrm{H}$ interaction with the surface of the carbon. The presence of amine groups are confirmed by the peaks observed at 1612 and $1575 \mathrm{~cm}^{-1}$ while the band at $1158 \mathrm{~cm}^{-1}$ is due to the $\mathrm{C}-\mathrm{N}$ stretching. The sharp absorption band at $1125 \mathrm{~cm}^{-1}$ is ascribed for C-O stretching in alcohol, ether or hydroxyl groups.

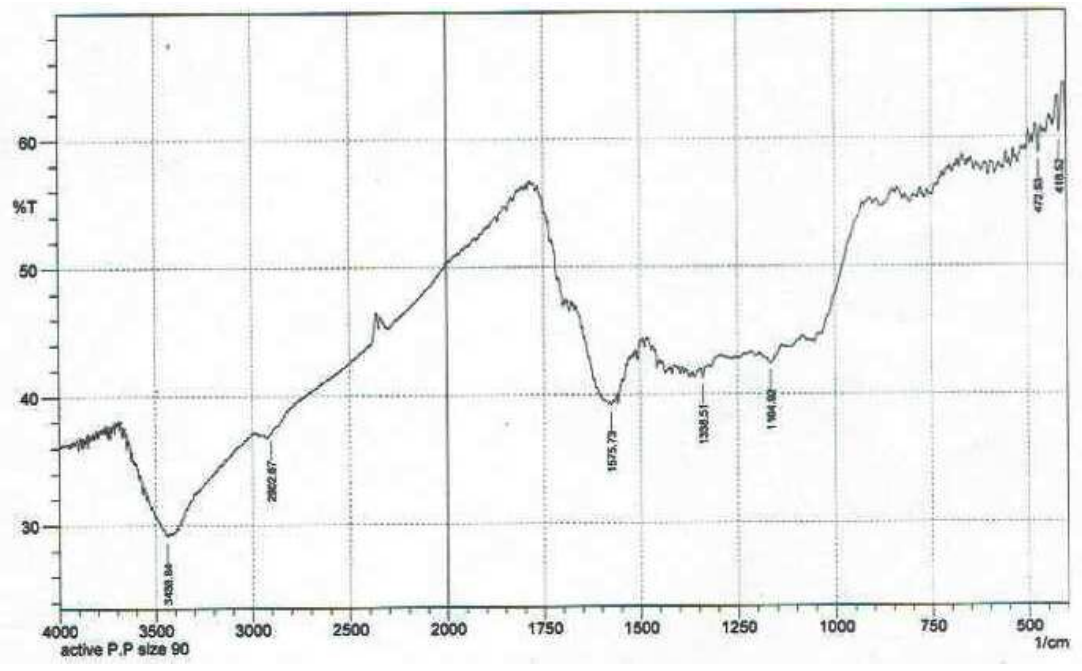

Figure 3. FTIR spectrum of prepared $A C(P P Z S) K O H$.

\subsubsection{Scanning Electron Microscope (SEM)}

The prepared activated carbon $\mathrm{AC}(\mathrm{PTLS}) \mathrm{ZnCl}_{2}$ was examined by Scanning Electron Microscope (SEM) to analyze the surface of the adsorbents. SEM micrograph of the chemically activated carbon by $\mathrm{KOH}$, was presented in Figure 4. Well-developed porous surface was observed at higher magnification. The pores observed from SEM imageis having diameter in micrometer $(\mu \mathrm{m})$ range. These pores are considered as channels to the microporous network. From the figure, it can be observed that, the adsorbent have rough texture with heterogeneous surface and a variety of randomly distributed pore size.

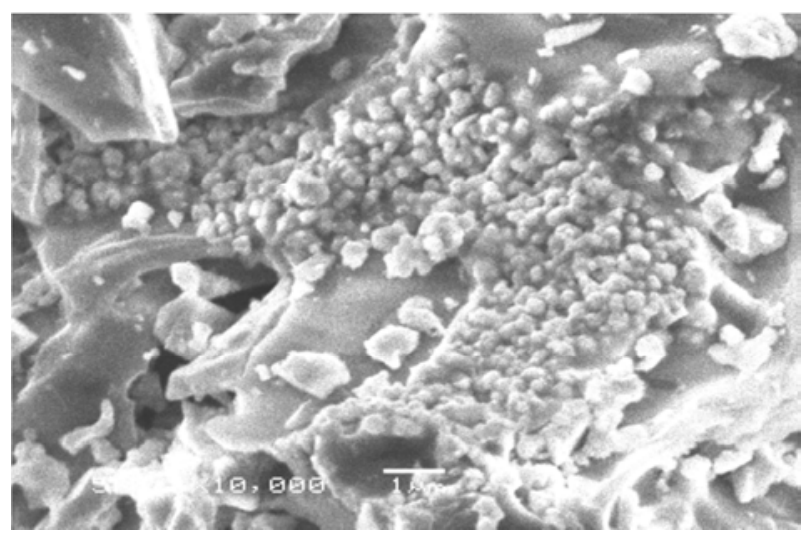

Figure 4. SEM image of the prepared $A C(P P Z S) K O H$, Magnification X10000.

\subsection{Effect of Process Parameters}

\subsubsection{Effect of $\mathrm{pH}$}

Solution $\mathrm{pH}$ is one of the important process parameters that significantly influences the adsorption of CIP on adsorbent [33, 34]. The adsorption of CIP from $50 \mathrm{mg} / \mathrm{L}$ concentration on given $\mathrm{AC}(\mathrm{PPZS}) \mathrm{KOH}$ was studied at $\mathrm{pH}$ ranging (2-12). The result in Figure 5, shows that the adsorption of CIP increased from the initial $\mathrm{pH}$ to 8 and then decreased over the $\mathrm{pH}$ rang of 9-12. Therefore, in this study we found that $\mathrm{pH} 8$ as the optimum $\mathrm{pH}$. At low $\mathrm{pH}$ region the surface of the adsorbent will be largely protonated. The positive ions $\left(\mathrm{H}^{+}\right)$provide an electrostatic attraction between the AC(PPZS)KOH surface and the drug molecules leading to maximum adsorption, $86.4 \% \pm 5.7$. On the other hand, at $\mathrm{pH}$ above 8 the degree of protonation of the surface of the $\mathrm{AC}(\mathrm{PPZS}) \mathrm{KOH}$ will be less, which result in the decrease in diffusion and adsorption, thereby due to electrostatic repulsion. Furthermore, lower adsorption of the Drug molecules in alkaline medium can be attributed to the competition from excess Hydroxide ions $\left(\mathrm{OH}^{-}\right)$with the drug molecules for the adsorption sites. 


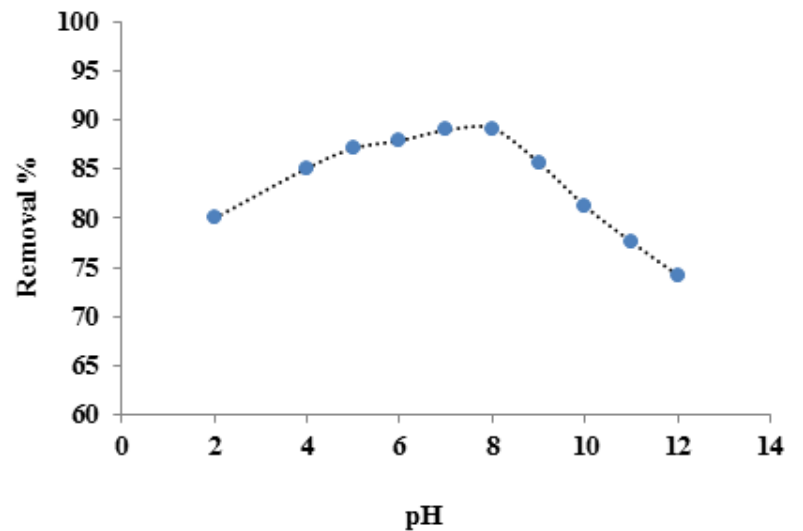

Figure 5. Effect of $p H$ on CIP removal by $A C(P P Z S) K O H$ (Initial concentration $-50 \mathrm{mg} / \mathrm{L}$, adsorbent dose $-0.050 \mathrm{~g}$, Agitation speed -100 rpm, contact time $-30 \mathrm{~min}$, and temperature $-25^{\circ} \mathrm{C}$ ).

\subsubsection{Effect of Adsorbent Dose}

The effect of adsorbent dose on removal percentage of CIP using $\mathrm{AC}(\mathrm{PPZS}) \mathrm{KOH}$ was illustrated in Figure 6. Different doses of adsorbents ranging from $0.025-0.200 \mathrm{~g}$ were considered and other process parameters were maintained constant $(\mathrm{pH}-8$, CIP concentration $-50.0 \mathrm{mg} / \mathrm{L}$, Agitation speed $-100 \mathrm{rpm}$, contact time $-30 \mathrm{~min}$, and temperature $\left.25^{\circ} \mathrm{C}\right)$.

An increase in adsorption capacity with increasing adsorbent dose up to a maximum of $0.05 \mathrm{~g}$ giving the corresponding optimum removal percentage of $89.68 \%$. On the other hand, it is found that any further addition over the above mentioned weight $(0.05 \mathrm{~g})$ will not make any enhancement in the adsorption process, where almost negligible increase of removal efficiency over the specific adsorbent dose. The initial increase in adsorption capacity with increasing adsorbent mass is explained by the increase in the number of exchangeable sites for CIP adsorption, after which equilibration was attained [16-19, 32, 34].

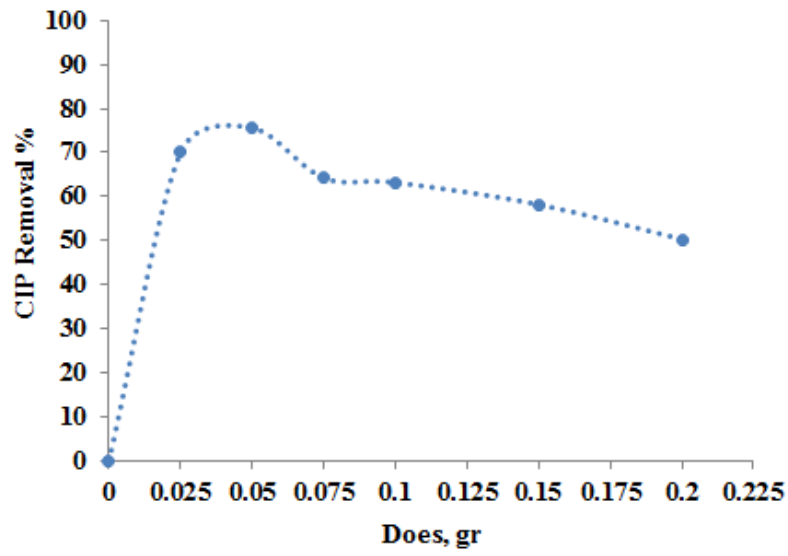

Figure 6. Effect of adsorbent dose on CIP removal by AC(PPZS)KOH ((pH8 , Initial concentration - $50 \mathrm{mg} / \mathrm{L}$, Agitation speed - $100 \mathrm{rpm}$, contact time$30 \mathrm{~min}$, and temperature $-25^{\circ} \mathrm{C}$ ).

\subsubsection{Effect of Contact Time}

The effect of contact time on the removal of CIP is shown in Figure 7. The amount of the adsorbed drug increases with increasing time until it levels off after some $30 \mathrm{~min}$. A constant adsorption is indicative of equilibration due to saturation of adsorption sites. Rapid adsorption of CIP drug during the initial stages was due to the large initial concentration gradient between the adsorbate in solution and the number of available vacant sites on $\mathrm{AC}(\mathrm{PPZS}) \mathrm{KOH}$ adsorbent surface [16-22, 32, 34].

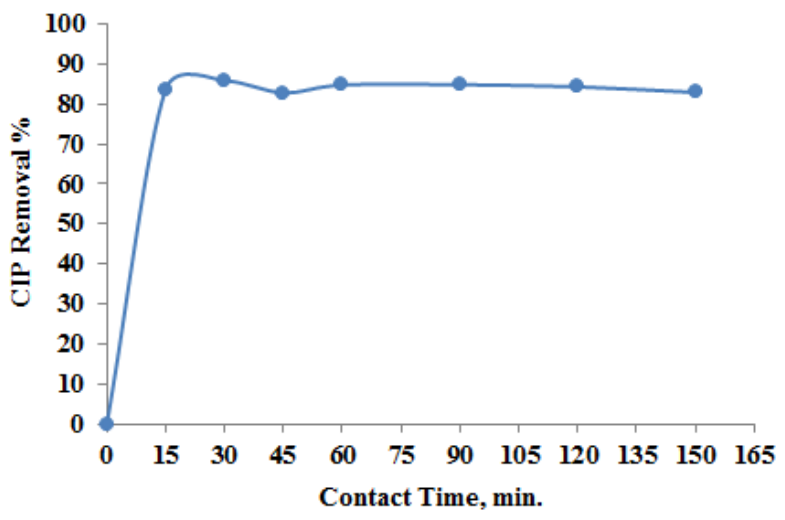

Figure 7. Effect of contact time on CIP removal by $A C(P P Z S) K O H(p H-8$, Initial concentration - $50 \mathrm{mg} / \mathrm{L}$, adsorbent dose - $0.050 \mathrm{~g}$, Agitation speed$100 \mathrm{rpm}$, and temperature $-25^{\circ} \mathrm{C}$ ).

\subsubsection{Effect of Initial Ciprofloxacin Concentration}

The initial concentration of CIP in the solution is an important parameter since its concentration change over a broad range in effluents applications.

The batch adsorption experiments were carried out with different initial concentrations $\left(C_{i}\right)(50,100,150,200,250$ and $300 \mathrm{mg} / \mathrm{L}$ ). The variation of percentage removal the drug with different initial concentration for the prepared activated carbon AC(PPZS)KOH was clarified in Figure 8. The figure shows a excellent performance of the prepared activated carbon at equilibrium state and clarify the optimum drug initial concentration used at confined experimental conditions.

It is also evidently observed that the percentage removal of the CIP drug is sufficiently high, $(86.4 \% \pm 4.73)$ at low concentration $(50 \mathrm{mg} / \mathrm{L})$ and no significant further increase as the concentration increases [15-25, 34].

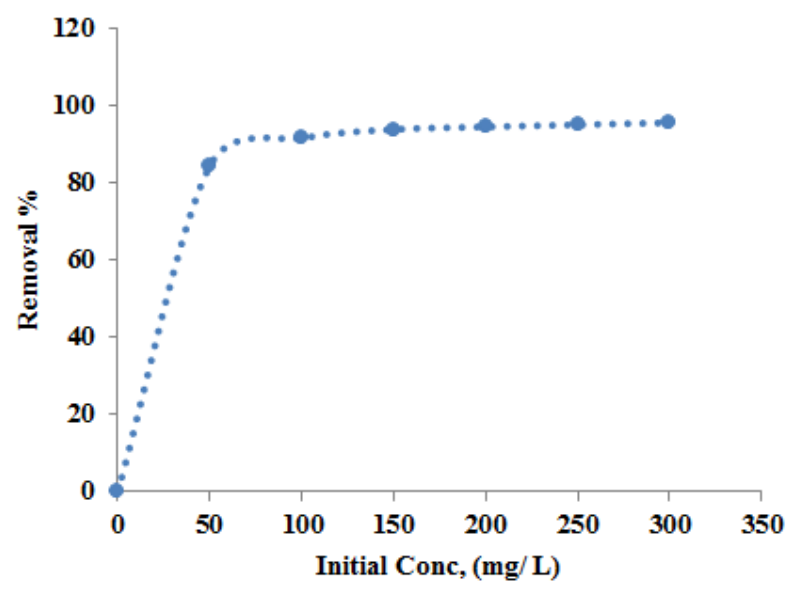

Figure 8. Effect of CIP initial concentration on its removal by $A C(P P Z S) K O H,(p H-8$, contact time $-30 \mathrm{~min}$, adsorbent dose $-0.050 \mathrm{~g}$, Agitation speed - $100 \mathrm{rpm}$, and temperature $-25^{\circ} \mathrm{C}$ ). 


\subsection{Adsorption Isotherms}

The successful representation of the dynamic adsorptive separation of solute from solution by an adsorbent depends upon a good description of the equilibrium between the two phases. Adsorption equilibrium is established when the amount of solute being adsorbed onto the adsorbent is equal to the amount being desorbed [15-27]. The equilibrium adsorption isotherms were depicted by plotting solid phase concentration $\left(q_{\mathrm{e}}\right)$ against liquid phase concentration $\left(C_{\mathrm{e}}\right)$ of solute.

Adsorption isotherm explains the interaction between adsorbate and adsorbent and is critical for design of adsorption process. The Freundlich and Langmuir isotherms are the most frequently used models to describe the experimental data of adsorption. In the present work these two isotherms were applied to investigate the adsorption process of CIP on prepared $\mathrm{AC}(\mathrm{PPZ}) \mathrm{KOH}$ at different conditions of process parameters.

\subsubsection{Freundlich Isotherm Model}

Freundlich isotherm is derived to a model of the multilayer adsorption and for the adsorption on heterogeneous surfaces, the linearized form of Freundlich equation is given by (15$18,35,36)$ :

$$
\ln \mathrm{q}_{\mathrm{e}}=\ln \mathrm{k}_{\mathrm{F}}+(1 / \mathrm{n}) \ln \mathrm{C}_{\mathrm{e}}
$$

where $\mathrm{k}_{\mathrm{F}}$ and $\mathrm{n}$ are Freundlich constants, $\mathrm{q}_{\mathrm{e}}$ is the extent of CIP adsorbed per unit mass of adsorbent $(\mathrm{mg} / \mathrm{g})$ and $\mathrm{C}_{\mathrm{e}}$ is the equilibrium concentration of CIP $(\mathrm{mg} / \mathrm{L})$. Aplot of $\log \mathrm{q}_{\mathrm{e}}$ against $\log \mathrm{C}_{\mathrm{e}}$ would give the values of $\mathrm{n}$ and $\mathrm{k}_{\mathrm{F}}$ from the slope and it ercept respectively. The slope of $1 / n$ ranging between 0 and 1 is a measure of adsorption intensity or surface heterogeneity, becoming more heterogeneous as its value gets closer to zero, while $\mathrm{k}_{\mathrm{F}}$ represents the quantity of adsorbate on to the adsorbent. The values of Freundlich constants with the correlation coefficients are shown in Table 1 and Figure 9. The results show a better fit of experimental data of CIP uptake by AC(PPZS)KOH waste, high agreement with Freundlich, and poor less fitting with Langmuir.

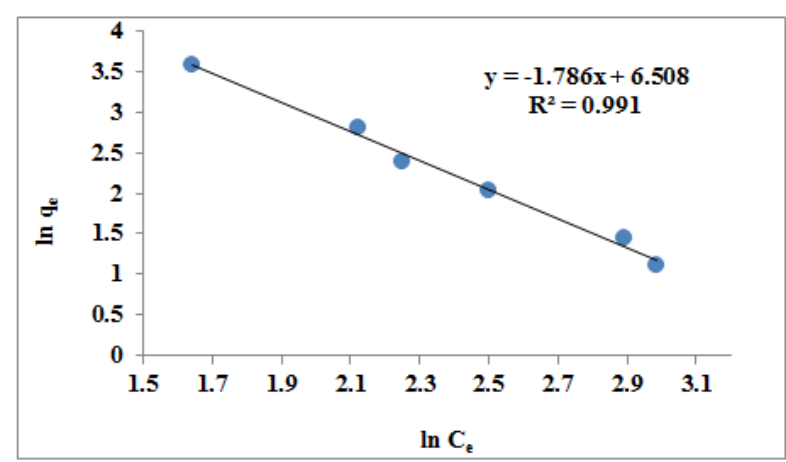

Figure 9. Freundlich isotherms of $A C(P P Z S) K O H$ for $C I P$ removal at $25^{\circ} \mathrm{C}$.

\subsubsection{Langmuir Isotherm Model}

To understand the adsorption isotherm, the Langmuir equation is perhaps the most widely used model due to its simplicity and Strong theoretical reasoning behind. This model suggests monolayer sorption on a homogeneous surface without interaction between sorbed molecules. In addition the model assumes uniform energies of sorption on to the surface and no transmigration of the sorbate. The linearized form of the Langmuir isotherm equation is represented as [15-28, 35]:

$$
\mathrm{C}_{\mathrm{e}} / \mathrm{q}_{\mathrm{e}}=1 / \mathrm{K}_{\mathrm{L}} \mathrm{q}_{\mathrm{m}}+\mathrm{C}_{\mathrm{e}} / \mathrm{q}_{\mathrm{m}}
$$

Where $\mathrm{q}_{\mathrm{e}}(\mathrm{mg} / \mathrm{g})$ is the amount adsorbed per unit mass of adsorbent corresponding to complete coverage of sites, $\mathrm{C}_{\mathrm{e}}(\mathrm{mg} / \mathrm{L})$ is the equilibrium concentration of CIP in solution, $\mathrm{q}_{\mathrm{m}}(\mathrm{mg} / \mathrm{g})$ is the monolayer adsorption capacity of the adsorbent and $\mathrm{K}_{\mathrm{L}}(\mathrm{L} / \mathrm{mg})$ is the adsorption energy. The related parameters are summarized in Table 1, and the linearized Langmuir equation is shown in Figure 10. The results reveal the Langmuir model is not able to describe the experimental data properly, poorless fitting on $\mathrm{AC}(\mathrm{PPZS}) \mathrm{KOH}$.

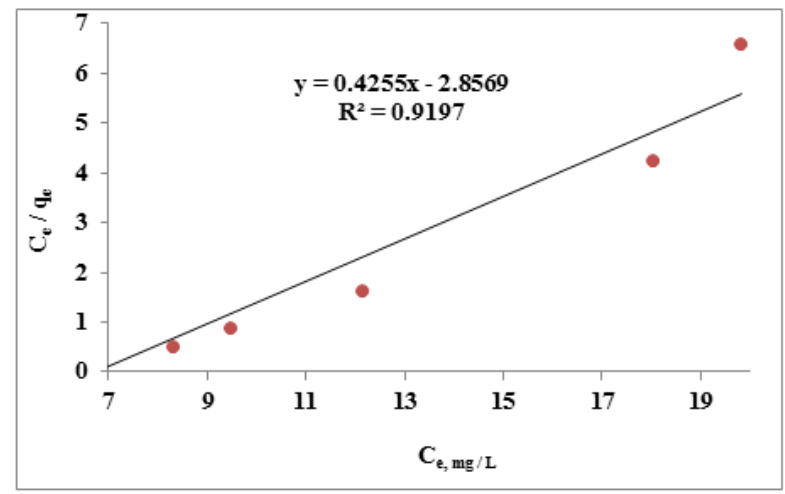

Figure 10. Langmuir isotherms of $A C(P P Z S) K O H$ for $C I P$ removal at $25^{\circ} \mathrm{C}$.

Table 1. Langmuir, Freundlich, isotherm constants for the CIP removal on the prepared $A C(P P Z S) K O H$ at $25^{\circ} \mathrm{C}$.

\begin{tabular}{llllll}
\hline Langmuir & \multicolumn{5}{c}{ Frenudlich } \\
\hline $\mathbf{K}_{\mathbf{L}}(\mathbf{L} / \mathbf{m})$ & $\mathbf{q}_{\mathbf{m}}(\mathbf{m g} / \mathbf{g})$ & $\mathbf{R}^{\mathbf{2}}$ & $\begin{array}{l}\mathbf{K}_{\mathbf{F}},[\mathbf{( m g} / \mathbf{g}) \\
\left.(\mathbf{L} / \mathbf{m g})^{\mathbf{1} \mathbf{n}}\right]\end{array}$ & $\mathbf{n}$ & $\mathbf{R}^{\mathbf{2}}$ \\
\hline 0.824 & 2.353 & 0.919 & 1.873 & 0.560 & 0.991 \\
\hline
\end{tabular}

\section{Conclusion}

The adsorption of Ciprofloxacin hydrochloride (CIP) onto Activated Carbon derived from Pomegranate Peel wastes collected from Alziedab Agricultural Scheme at River Nile state, Sudan has been studied. Adsorption experiments were tested at various parameters such as sorbent dosage, contact time, $\mathrm{pH}$, and CIP concentration. The equilibrium data were analyzed using Freundlich and Langmuir, isotherm models and the results are well fitted to Freundlich equations. It was found that the equilibrium was reached within $30 \mathrm{~min}$; also it was found that the optimum $\mathrm{pH}$ value of the CIP adsorption was 8 . The present work concludes that $\mathrm{AC}(\mathrm{PPZS}) \mathrm{KOH}$ agricultural wastes is effective adsorbent in removing CIP from aqueous solutions. The optimum conditions which have been obtained in adsorption process for treating the aqueous phase were $50 \mathrm{mg} / \mathrm{L}$ for initial CIP concentration, $8 \mathrm{pH}$ for 
solution alkalinity, and $2.50 \mathrm{~g} / \mathrm{L}$ for mass of adsorbent. The equilibrium data obtained for the prepared activated carbon, $\mathrm{AC}(\mathrm{PPZS}) \mathrm{KOH}$, is fitted to the Freundlich model more than the Langmuir. It was observed that the Freundlich adsorption isotherm conforms to the adsorption of CIP from aqueous solutions using $\mathrm{AC}(\mathrm{PPZS}) \mathrm{KOH}$, the level of conformity is to a high extent compared to the Langmuir adsorption isotherms as indicated by higher correlation coefficient values of 0.991 .

\section{Acknowledgements}

We gratefully acknowledge the helpful assistants by all members ofChemical Laboratories at University of Khartoum, and National Center for Research, Khartoum Sudan.

\section{References}

[1] Caliman, F. A., \& Gavrilescu, M. "Pharmaceuticals, Personal Care Products and Endocrine Disrupting Agents in the Environment"- A Review. CLEAN -Soil, A ir, Water, pp 277 303, 2009.

[2] Fick, J., Söderström, H., Linderberg, R. H., Phan, C., Tysklind, M., \& Joakim Larsson, D, "Contamination of Surface, Ground, and Drinking Water from Pharmaceutical Production", Environmental Toxicology and Chemistry, pp 2522-2527, 2009

[3] Giger, W., Alder, A. C., Golet, E. M., Kohler, H.-P. E., Mc Ardell, C. S., Molnar, E., "Occurence and Fate of Antibiotics as Trace Contaminants in Wastewaters, Sewage Sludges, and Surface Waters", Chimia 57, pp 485-491, 2003.

[4] Dror Avisar, Orna Primor, Igal Gozlan and Hadas Mamane, "Sorption of Sulfonamide Tetracyclines to Montmorillonite Clay", Water Air Soil Pollut., 209, 1-4, pp 439-450, 2010.

[5] Kolpin, D. W.; Furlong, E. T.; Meyer, M. T.; Thurman, E. M.; Zaugg, S. D.; Barber, L. B.; Buxton, H. T, "Pharmaceuticals, hormones, and other organic waste water contaminants in U.S. streams, 1999-2000:

[6] Glen D. Park, Pharm D; Reynold Spector, MD; Mark J. Goldberg, MD and George F. Johnson, "Expanded Role of Charcoal Therapy in the Poisoned and Overdosed Patient", Arch Intern. Med. 146(5), pp. 969-973, 1986.

[7] Cassidy S. L., Hale A., Buss D. C. and Routledge P. A., "Invitro drug adsorption to charcoal, silicats, acry late copolymer and silicon oil with charcoal and with acrylate copolymer", Hum. Exp. Toxicol., 16 (1), pp 25-27, 1997.

[8] Reem Adham AL-Bayati," Adsorption- Desorption Isotherm of One of Antidibetic Drug from Aqueous Solutions on Some Pharmaceutical Adsorbents", European Journal of Scientific Research, 40,. 4, pp.580-588, 2010.

[9] Figueroa, R. A., Leonard, A., \& Mackay, A. A, "Modeling tetracycline antibioticsorption in clays", Environmental Science \& Technology, 38, pp 476-483, 2004.

[10] Ter Laak, T. L., Gebbink, W., \& Tolls, J., "The effect of pH and ionic strength on the sorption of sulfachloropyridazine, tylosin, and oxytetracycline to soil", Environmental Toxicology \& Chemistry, 25(4), pp 904-911, 2006.
[11] Omar S. Alkhazrajy, Maha A. Al-Abayaji and Mohammed H. Abdul Latif, "Adsorption of Metoclopromide Hydrochloride onto burned initiated Iraqibentonite", journal of Alnahrain University, 15(2), pp 35-46, 2012.

[12] Isa. S. A., Jasim S. M., and Hussein H. K., "Investigation of bentonite clay surface asaphysical antidote of Amitriptyline $\mathrm{HCl}$, chlorpromazine $\mathrm{HCl}$ and Chlordizepoxide $\mathrm{HCl}$ from solution", J. Iraqi Pharm. 8 (2), pp 62-68, 2002.

[13] Al-Tamimi. R. J.," Study of the ability of selected surface in adsorption of somdrugs from solution", Msc. Thesis, college of Science, University of Baghdad, 2002.

[14] Rossi S, "Australian Medicines Handbook" ( $2^{\text {nd }}$ ed). Adelaide, 2006.

[15] Carabineiro, S. A. C., Thavorn-amornsri, T., Pereira, M. F. R., Serp, P., Figueiredo, J. L.: Comparison between activated carbon, carbon xerogel and carbon nanotubes for the adsorption of the antibiotic ciprofloxacin. Catalysis Today, 186, 29 -34 (2012).

[16] Ibezim, E. C., Ofoefule, S. I., Ejeahalaka, C. N. E., Orisakwe, O. E.: In vitro adsorption of ciprofloxacin on activated charcoal and talc. American Journal of Terapeutics, 6(4), 199-201 (1999).

[17] El-Shafey, E. S. I., Al-Lawati, H., Al-Sumri, A.S.: Ciprofloxacin adsorption from aqueous solution onto chemically prepared carbon from date palm leaflets. Journal of Environmental Sciences, 24(9), 1579-1586 (2012).

[18] Wu, Q., Li, Z., Hong, H.: Influence of types and charges of exchan geable cations on ciprofloxacin sorption by montmorillonite. Journal of Wuhan University of TechnologyMaterials Science, 27(3), 516-522 (2012).

[19] Carrasquillo, A. J., Bruland, G. L., Mackay, A. A., Vasudevan, D.: Sorption of ciprofloxacin and oxytetracycline zwitterions to soils and soil materials: influence of compound structure. Environmental Science and Technology, 42, 7634-7642 (2008).

[20] Vasudevan, D., Bruland, G. L., Torrance, B. S., Upchurch, V. G., Mac Kay, A. A.: pH-dependent ciprofloxacin sorption to soil: Interaction mechanisms and soil factors influencing sorption. Geoderma, 151, 68-76 (2009).

[21] Conkle, J. L., Lattao, C., White, J. R., Cook, R. L.: Competitive sorption and desorption behavior for three fluoroquinolone antibiotics in a waste water treatment wetland soil. Chemosphere, 80(11), 1353-1359 (2010).

[22] Wang, C. J., Li, Z., Jiang, W. T.: Adsorption of ciprofloxacin on 2:1 dioctahedral clay minerals. Applied Clay Science, 53,723-728 (2011).

[23] Li, Z., Hong, H., Liao, L., Ackley, C. J., Schulz, L. A., MacDonald, R. A., Mihelich, A. L., Emard, S. M.: A mechanistic study of ciprofloxacin removal by kaolinite. Colloids and Surfaces B: Biointerfaces, 88, 339-344 (2011).

[24] Zhang, C. L., Qiao, G. L., Zhao, F., Wang, Y.: Thermodynamic and kinetic parameters of ciprofloxacin adsorption onto modified coal fly ash from aqueous solution. Journal of Molecular Liquids, 163, 53-56 (2011).

[25] Wu, C., Spongberg, A. L., Witter, J. D.: Sorption and biodegradation of selected antibiotics in biosolids. Journal of Environmental Science and Health Part A, 44: 454-461 (2009). 
[26] Bajpai, S. K., Bajpai, M., Rai, N.: Sorptive removal of ciprofloxacin hydrochloride from simulated wastewater using sawdust: Kinetic study and effect of pH. Water SA, 38(5), 673-682 (2012).

[27] Jiang, W. T., Chang, P. H., Wang, Y. S., Tsai, Y., Jean, J. S., Li, Z., Krukowski, K.: Removal of ciprofloxacin from water by birnessite. Journal of Hazardous Materials, 250-251, 362-369 (2013).

[28] Shi, S., Fan, Y. W., Huang, Y. M.: Facile low temperature hydrothermal synthesis of magnetic mesoporous carbon nanocomposite for adsorption removal of ciprofloxacin antibiotics. Industrial \& Engineering Chemistry Research, 52(7), 2604-2612 (2013).

[29] Reynaud, F., Tsapis, N., Deyme, M., Vasconcelos, T. G., Gueutin, C., Guterres, S. S., Pohlmann, AR, Fattal, E.: Spraydried chitosan-metal microparticles for ciprofloxacin adsorption: Kinetic and equilibrium studies. Soft Matter, 7(16), 7304-7312 (2011).

[30] Gu, C., Karthikeyan, K. G.: Sorption of the antimicrobial ciprofloxacin to aluminum and iron hydrous oxides. Environmental Science and Technology, 39, 9166-9173 (2005).

[31] Rakshit, S., Sarkar, D., Elzinga, E. J., Punamiya, P, Datta, R.: Mechanisms of ciprofloxacin removal by nano -sized magnetite. Journal of Hazardous Materials, 246-247, 221-226 (2013).
[32] Edith Cristina Laignier Caze dey, Hérida Regina Nunes Salgado., Spectrophotometric Determination of Ciprofloxacin Hydrochloride in Ophthalmic Solution., Advances in Analytical Chemistry 2012, 2(6): 74-79.

[33] Affo, W., Mensah-Brown, H., Awuku, J. F., Markwo, A. Quantitative Analysis of Ciprofloxacin Sodium Chloride Pharmaceutical Infusions Using Ultraviolet-visible Spectroscopy., ARPN Journal of Science and Technology., Vol. 3, NO. 3, March 2013.

[34] Dhafir T. Ajeel Al-Heetimi, Muna Abdul Rasool Kadhum and Omar S. Alkhazrajy., Adsorption of Ciprofloxacin Hydrochloride from Aqueous Solutionby Iraqi Porcelinaite Adsorbent., Journal of Al-Nahrain University Vol. 17 (1), March, 2014, pp.41-49.

[35] Choy, K. K. H., Porter, J. F., McKay, G. Langmuir isotherm models applied to the multi component sorption of acid dyes from effluent onto activated carbon, Chemical Engineering Journal, 45, 2000, 575-584.

[36] Mutasim H. Elhussien, Yusuf M Isa., 2015- Langmuir, Freundlich Adsorption Isotherms and Kinetics for the Removal of Methylene Blue Dye from Aqueous Solution using Activated Carbon Derived from Pods of Acacia nilotica var astringens (Sunt tree) by Chemical Activation with $\mathrm{ZnCl}_{2}$, Chemical Process and Engineering Research, vol. (38): 2534. 